\title{
University of Nebraska Medical Center Nebraska Medicine
}

Graduate Medical Education

\section{Research Journal}

Volume 2 | Issue 1

Article 88

September 2020

\section{Ham in Nose}

Elizabeth Null

University of Nebraska Medical Center

Tell us how you used this information in this short survey.

Follow this and additional works at: https://digitalcommons.unmc.edu/gmerj

Part of the Higher Education Commons, Medicine and Health Sciences Commons, and the Nonfiction Commons

\section{Recommended Citation}

Null, E. Ham in Nose. Graduate Medical Education Research Journal. 2020 Sep 29; 2(1).

https://digitalcommons.unmc.edu/gmerj/vol2/iss1/88

This Creative Work is brought to you for free and open access by DigitalCommons@UNMC. It has been accepted for inclusion in Graduate Medical Education Research Journal by an authorized editor of DigitalCommons@UNMC.

For more information, please contact digitalcommons@unmc.edu. 


\section{Ham in Nose}

Creative Commons License

(C) $(\mathbb{\theta} \Theta \Theta$

This work is licensed under a Creative Commons Attribution-Noncommercial-No Derivative Works 4.0 License. 


\section{Ham in Nose}

Elizabeth Null

${ }^{1}$ University of Nebraska Medical Center, Department of Pediatrics

New landlord: 2 year-old female. I know because you appeared on my ordinary mid-afternoon clinic schedule in a string of boldened capital letters. These encountersthey are added to the well of bizarre medical interventions to reminisce fondly on during the monotonous winter months of pediatric training.

Metallic rainbow Velcro shoes carry a tousled blonde mop of bouncing curls nonchalantly to the exam room.

Dark brown eyes glare skeptically through still curls. They meet mine evenly as I lower the chair to the ground, then lock onto the foreign object I take out from a cupboard, the one watched closely by the green birds atop purple mountains framed on the adjacent wall. I extend my left index finger towards the beam of otoscopic light to cover it. After pause, she cannot resist doing the same. We both marvel at the fingertip aglow.

"See, it doesn't hurt."

I proceed with shining light up the area of interest. And there you are, unveiling a flirtatious vertex, nestled deep in the right nares. She blows into my hand, I massage from above. We repeat until her nasal orifice swiftly births your cubed centimeter of sweating swine flesh, now safely extracted.

The curls resume their bounce, this time with belly laughter that mimics mine.

You sit atop a pillow of tissues on the counter with an accomplished presence, the object of parental disbelief, honest as the complaint you caused. A singular diagnosis and simultaneous, soul-satisfying cure. 